\title{
KONSUMERISME DAN GAYA HIDUP PEREMPUAN DI RUANG SOSIAL: ANALISIS BUDAYA PEMBEDAAN DIRI DI LINGKUNGAN FISIP UNIMAL
}

\author{
Rahmi Rachel, Rakhmadsyah Putra Rangkuty ${ }^{1)}$ \\ ${ }^{1}$ Program Studi Sosiologi FISIP Universitas Malikussaleh, oecoex@ gmail.com
}

\begin{abstract}
This study focuses on the objectives of being different and consumption behavior among students. This study uses the theory of habitus and environment according to Pierre Bourdieu. The method used is qualitative research with a descriptive approach in order to describe and obtain information on what female students are doing to be different and consumption behavior in their social space. The results of this study found that there are several factors that influence female students to be different. First, they want to be the center of attention for others. Second, being different is done in order to attract the attention of men in the environment. Third, someone takes action to be different because they want to be a trendsetter, feel different and attractive makes a woman feel happy, and becomes a woman's pride. Fourth, be more confident. All of that encourages consumptive behavior where consuming an item is no longer a fulfillment of a need but only because you want to appear different from others or are afraid to look the same or similar to others.
\end{abstract}

Keywords: Fashion, Different Appearances, Consumptive Behavior, Habitus

\begin{abstract}
ABSTRAK
Penelitian ini memfokuskan pada tujuan tampil beda dan perilaku konsumsi di kalangan mahasiswi dengan menggunakan teori habitus dan lingkungan menurut Pierre Bourdieu. Metode yang digunakan adalah penelitian kualitatif dengan pendekatan deskriptif agar dapat menggambarkan dan memperoleh informasi tentang apa yang dilakukan oleh mahasiswi untuk tampil beda melalui perilaku komsumsi di ruang sosialnya. Hasil dari penelitian ini menemukan bahwa terdapat beberapa faktor yang mempengaruhi mahasiswi untuk tampil beda. Pertama, adanya keinginan menjadi pusat perhatian bagi orang lain. Kedua, tampil beda dilakukan dengan tujuan menarik perhatian lawan jenis yang yang ada di lingkungan tersebut. Ketiga, seseorang melakukan tindakan tampil beda karena ingin menjadi pencipta tren, merasa berbeda dan menarik membuat rasa senang, dan menjadi kebanggaan tersendiri bagi seorang perempuan. Keempat, menjadi lebih percaya diri. Semua itu mendorong perilaku konsumtif dimana mengonsumsi suatu barang bukan lagi sebagai pemenuhan kebutuhan melainkan hanya karena ingin tampil berbeda dari orang lain atau takut terlihat sama atau mirip dengan yang lain.
\end{abstract}

Kata Kunci: Mode, Tampil Beda, Perilaku Konsumtif, Habitus 


\section{PENDAHULUAN}

“Cogito, ergo sum”, aku berpikir maka aku ada. Sekarang pernyataan tersebut semakin kehilangan maknanya, dikalahkan oleh slogan "I shop therefore I am"—aku berbelanja, maka aku ada. Semangat berkonsumsi masyarakat modern mencerminkan realitas tersebut, sebagai bagian dari kehidupan sosial masyarakat konsumen (Soedjatmiko, 2008). Budaya konsumen sudah membingkai alam berpikir masyarakat (Ulfa, 2008) yang ditunjukkan melalui gaya hidup, selera, dan cita rasa. Hal ini dilakukan dalam konteks memperjuangkan posisi sosial (Lury, 1998).

Fenomena ini tampak mencolok pada cara seseorang berpakaian. Pada hakikatnya, pakaian adalah kebutuhan primer dan sarana menegakkan norma. Namun seiring perkembangan zaman pakaian sudah diposisikan sebagai gaya hidup yang memiliki makna sosial, yakni sebagai ekspresi identitas si pemakai dan ekspresi kelas sosial. Hal itu dilakukan dalam rangka meraih posisi sosial yang ditunjukkan melalui gaya hidup boros dan pembelian barang dan jasa sebagai sumber kesenangan dan kemewahan (Veblen dalam Bakti, et al., 2020). Orang-orang membeli barang atau memakai jasa bukan untuk kebutuhan tetapi untuk memuaskan keinginan, sedangkan keinginan tersebut tidak akan pernah terpuaskan. Seiring waktu pakaian menjadi komoditas yang paling menguntungkan, di sini lahirlah perusahaan-perusahaan produsen yang menawarkan produk pakaian dengan berbagai merk dan desain seperti Channel, Levi's, Dior, Zara, dan lain-lain.

Budaya konsumerisme ini juga melekat pada perempuan. Seorang perempuan cenderung digambarkan lebih konsumtif daripada pria karena kebutuhannya yang berbeda. Penampilan menjadi salah satu bagian penting dalam dunia perempuan. Rasa ingin tampil cantik memaksa terjadinya kontestasi konsumsi fashion dalam bingkai gaya hidup atau lifestyle (Pratiwi \& Bharata, 2012). Diri seorang perempuan kemudian diasosiasikan dengan merk produk tertentu. Perempuan memang saling berkompetisi dengan sesamanya, bahkan dengan teman sendiri. Bisa dikatakan sebenarnya, perempuan mana yang tidak senang atau bahagia jika dikatakan lebih hit, trendsetter,

paling cantik, paling bagus, dan paling lainnya. Senang sudah pasti dan rasa bangga akan menjadi kelanjutan dari akibat pujian tersebut.

Keinginan berbeda dan mempertahankan perbedaan bertautan dengan tanda-objek yang dikonsumsi, memberi makna tentang status sosial (Ritzer, 2010). Perempuan sebagai penghuni ruang sosial, sangatlah memperhatikan penampilannya. Penampilan juga dianggap sebagai modal utama dalam menghadapi dunianya. Bagi perempuan menjaga penampilan sama dengan menjaga image-nya. Perhatian perempuan atas penampilan dirinya dan orang lain di ruang sosial yang dilingkupi budaya konsumerisme sangatlah penting. Perempuan cenderung menghindari penampilan atau sesuatu yang ia kenakan sama ataupun nyaris sama dengan orang lain. 
Penampilannya haruslah yang paling menarik, dan penampilan menarik tidaklah statis, maka tampil beda setiap hari menjadi hal penting. Budaya tampil beda, hasrat untuk tampil dengan penampilan tunggal, bahwa orang lain tidak bisa atau tidak boleh berpenampilan sama, hal seperti itu dikejar untuk memperoleh pengakuan dari orang lain, bahwa yang menarik dan fashionable adalah dirinya, dan siapa yang tampil sama atau nyaris sama, akan menjadi pesaing.

Dari budaya pembedaan diri inilah perempuan terus bersaing, menunjukkan bahwa dialah yang paling menarik, dapat kita lihat contoh pada trend jilbab. Jilbab di Aceh khususnya menjadi pakaian primer bagi perempuan muslim saat hendak pergi keluar rumah. Maka penggunaan jilbab juga berlaku budaya pembedaan diri, perempuan yang selalu ingin tampil beda akan selalu memperhatikan pakaiannya. Ia menjaga cara berbusana. Fashion menjadi modal utama menghadapi ruang sosialnya.

Faktanya di Universitas Malikussaleh, khususnya di lingkungan FISIP, pembedaan ini juga terjadi. Contoh kecil yang dapat kita lihat misalnya pada penggunaan jilbab. Dengan berkembangnya zaman, model-model jilbab ikut berkembang, mulai dari jilbab segi empat, pashmina, jilbab instan, hingga trend hijab syar'i. Dari berbagai jenis dan model jilbab dan fashion inilah seseorang mulai membangun identitas, tampilan, perilaku, dan gaya.

Observasi awal di lapangan menunjukkan bahwa tak ada satu pun perempuan yang ingin terlihat sama dengan yang lain, bahkan teman mereka sendiri, dari mulai yang terlihat update dengan gayanya hingga yang bergaya biasa-biasa saja. Mereka merasa risih melihat orang lain memakai suatu barang yang sama atau terlihat mirip dengan milik mereka. Mereka merasa harus langsung mengganti pakaian mereka atau pergi menjauh hingga tak ada yang mengatakan sama atau terlihat sama dengan yang lain. Bahkan dengan adanya fenomena "genk" (biasanya para anggota senang terlihat sama) sekalipun perempuan akan merasa risih dengan teman seanggota jika menggunakan barang yang mirip tanpa persetujuan sebelumnya (janjian).

Mereka mempersonalisasi barang-barang, tanpa melakukan pengecekan terhadap barang, misalnya di mana barang tersebut diproduksi, berapa banyak barang tersebut dalam sekali produksi. Biasanya mereka hanya melihat tampilan luar bahwa hanya ada satu barang di toko tersebut, atau mereka biasanya hanya memperhatikan barang tersebut dari bahan apa. Mereka tidak mencari pengetahuan lebih lanjut tentang barang yang akan dibeli apakah akan ada di toko atau tempat lain. Mereka hanya memikirkan bagaimana caranya agar tampil berbeda dari yang lain, bahwa dialah yang memiliki tampilan seperti itu, berpikir dialah aktor tunggal dari penampilannya. Maka dengan ini peneliti tertarik meneliti fenomena tersebut dengan judul "Konsumerisme dan Gaya Hidup 
Perempuan di Ruang Sosial: Analisis Budaya Pembedaan Diri (Diferensiasi Personal) di Lingkungan FISIP Unimal”.

Penelitian terdahulu dilakukan oleh Astuti (2013) dimana diperoleh temuan bahwa subjek penelitian yang merupakan ibu rumah tangga, melakukan pembelian barang tanpa adanya perencanaan, tidak mempertimbangkan manfaat maupun kegunaan, melainkan demi menjaga penampilan diri dan gengsi, serta simbol status. Hal ini tampaknya mendukung studi yang dilakukan oleh Hotpascaman S (2010) yang menghasilkan temuan adanya korelasi yang signifikan antara perilaku konsumtif dengan konformitas supaya diterima dalam anggota kelompoknya. Sementara penelitian oleh Pratiwi (2015) menyimpulkan bahwa konsumsi motor Kawasaki yang dilakukan oleh sebuah komunitas terkait dengan nilai-guna dan nilai-tanda. Namun ketiga studi sebelumnya tidak melihat konsumsi yang dilakukan oleh subjek penelitiannya dari perspektif pembedaan diri (diferensiasi personal).

\section{Distingsi (Pembedaan)}

Menurut Bourdieu habitus dan lingkungan memiliki relasi yang bercorak timbal balik. Di satu sisi habitus dikondisikan oleh lingkungan, di sisi lain lingkungan diberi makna oleh habitus (Ritzer \& Goodman, 2003). Teori Bourdieu tentang habitus dan arena sangat berkaitan dengan penelitian tentang konsumerisme dan gaya hidup perempuan di ruang sosial, khususnya analisis budaya diferensiasi personal di lingkungan FISIP Unimal dimana tindakan seseorang ditentukan oleh habitus dan lingkungan. Adapun yang dimaksud habitus di sini ialah kerangka tindakan seseorang (mahasiswi). Sementara kaitannya dengan konsumerisme atau lebih khususnya pada penggunaan pakaian, seseorang menjadikan desain, warna, dan harga sebagai substansi pakaian karena hal itu dipersepsikan sebagai sesuatu yang eksklusif. Orang lain kemudian memiliki kerangka berpikir seperti itu karena terpengaruh sehingga membuat orang lain berpenampilan berbeda. Ada kerangka berpikir yang melihat cara berpakaian itu sebagai sesuatu yang mewah dan seharusnya dilakukan. Cara-cara membedakan diri itu kemudian menyebar, sehingga menghasilkan tindakan-tindakan yang sama dan berulang di lingkungan itu dalam hal membedakan diri dari yang lain dan menjadi kebiasaan di lingkungan FISIP Unimal.

Bourdieu selanjutnya menyatakan bahwa tujuan pembedaan diri sebagai demonstrasi kelas sosial dalam masyarakat, dikenal dengan konsep distingsi. Distingsi menelurkan selera yang variatif, objek kultural diapresiasi secara berbeda. Hal ini dipraktikkan dan diajarkan sehingga selera yang sama mampu menyatukan kelompok tertentu. Individu kemudian menempatkan dirinya pada kelompok dengan selera yang sama. Penonjolan ini dilakukan demi kehormatan dan eksistensi 
diri di dalam ruang sosial (Ritzer \& Goodman, 2003). Selera menyatukan kelompok sekaligus memisahkannya dengan kelompok lain yang memiliki selera berbeda. Jadi penggolongan diri di dalam suatu kelompok dilakukan baik oleh dirinya terhadap orang lain, ataupun sebaliknya, orang lain juga ikutserta menggolongkan dirinya berada di kelompok mana (Bourdieu dalam Jenkins, 2004).

\section{Konsumerisme, Gaya Hidup, dan Citra Diri}

Konsumerisme adalah sebuah paham atau ideologi. Dalam bingkai konsumerisme seseorang berkonsumsi secara berlebihan atau tidak sepantasnya. Hal ini dilakukan secara sadar dan berkelanjutan karena sudah menjadi cara hidup (Bakti, et al., 2019). Manusia mencandui produk. Apabila seseorang konsumtif dan menjadikannya sebagai gaya hidup maka orang tersebut menganut konsumerisme. Pola pikir ini mendorong seseorang mengonsumsi produk bukan karena kebutuhan, tetapi karena keinginan (Wahyudin \& Purwaningwulan, 2017).

Konsumsi, di dalam masyarakat kapitalisme global tidak sekedar sarana pemenuhan nilai kegunaan dalam pengertian sempit, akan tetapi merupakan cara membangun nilai-nilai simbolik. Konsumsi kini membentuk gaya hidup konsumtif yang ditopang oleh proses penciptaan diferensiasi secara kontinue melalui mekanisme tanda, citra, dan makna-makna simbolik (Piliang, 2011). Penelitian ini berkaitan dengan konsumerisme. Untuk terus eksis di ruang sosialnya, seseorang harus menjadi berbeda dari yang lain. Untuk terus tampil berbeda seseorang dalam ruang sosialnya harus terus menerus berkonsumsi, menjadikan seseorang pecandu dari suatu barang yang harus ia beli secara terus-menerus karena tak ingin terlihat sama terutama dalam penggunaan pakaian di ruang sosialnya.

Konsumerisme ditopang oleh gaya hidup yang dapat menjelaskan makna tindakan konsumtif seseorang (Chaney, 1996). Gaya hidup secara luas terkait dengan aktivitas, minat, dan opini yang bergerak secara dinamis, meskipun tidak cepat berubah dalam kurun waktu tertentu (Sari, 2015). Kamu bergaya, maka kamu ada. Dari gaya hidup sendiri yang sering diartikan sebagai cara orang menghabiskan waktu untuk aktivitasnya, hubungannya dalam penelitian penulis, mahasiswi di FISIP Unimal memilih model gaya hidup dalam ruang sosialnya adalah pencarian identitas dan sensibilitas untuk mencapai pengakuan bahwa dia (mahasiswi) mempunyai gaya yang berbeda, merasa unik dari yang lain, penampilan merupakan hal utama di lingkungannya. Gaya hidupnya di ruang sosial menunjukkan kelasnya.

Sementara itu, citra diri (self image) merupakan gambaran seseorang tentang dirinya yang sering terkait dengan citra fisik, khususnya penampilan. Citra diri menurut Chaplin (dalam 
Ramadhani \& Putrianti, 2014), yaitu kesan yang diidealkan. Citra diri sendiri sangat berkaitan dengan penelitian penulis, dimana seorang mahasiswi akan membuat citranya sendiri dalam menghadapi ruang sosialnya. Dengan dia membuat dirinya berbeda dengan orang lain, maka orang lain akan memiliki pandangan terhadapnya bahwa dia (mahasiswi) berbeda, unik, tidak memiliki gaya yang sama. Tampil beda akan memperoleh pengakuan, pujian, dan menempatkan ia di kelas yang berbeda dari orang lain.

\section{METODE PENELITIAN}

Penelitian ini dilaksanakan di kampus Universitas Malikussaleh yaitu tepatnya pada Fakultas Ilmu Sosial dan Ilmu Politik dengan menjadikan mahasiswi sebagai subjek penelitian. Metode penelitian yang digunakan adalah metode kualitatif yang menekankan pada dinamika dan proses serta bermaksud untuk memahami apa yang dialami subjek penelitian (Moleong, 2014) yaitu budaya diferensiasi personal mahasiswi yang tak ingin terlihat sama dengan mahasiswi lainnya. Peneliti memilih informan secara sengaja, yaitu para mahasiswi Program Studi Sosiologi sebanyak 6 (enam) orang, dengan ketentuan adanya figur dominan yang menginginkan kontinuitas, identitas, dan pengetahuan mengenai konsumerisme dan gaya hidup. Pencatatan sumber data melalui wawancara atau pengamatan hasil gabungan dari kegiatan melihat, mendengar, dan bertanya. Berbagai sumber data yang akan dimanfaatkan dalam penelitian ini antara lain data lapangan dan data kepustakaan. Teknik pengumpulan data yang digunakan yaitu observasi, wawancara, dan dokumentasi. Sementara analisis data dilakukan dengan langkah-langkah: 1) reduksi data, 2) penyajian data, dan 3) penarikan kesimpulan (Sugiyono, 2013).

\section{TUJUAN PEREMPUAN TAMPIL BEDA}

Mengukir nama berarti membuat tanda, mencapai pengakuan atas perbedaan seseorang dengan orang lainnya. Memperkenalkan perbedaan berarti menciptakan waktu. Di dalam pergulatan hidup dan pergulatan mencapai kesuksesan, letak pentingnya tanda-tanda distingtif yang tujuan akhirnya adalah mengidentifikasi apa yang menjadi properti paling superfisial dan kasat mata dari sebuah karya. Tanda-tanda distingtif ini menghasilkan eksitensi di dalam sebuah dunia di mana satu-satunya cara untuk eksis adalah menjadi berbeda, 'mengukir nama' secara pribadi maupun kelompok (Bourdieu, 2010). Dari hasil penelitian yang menjadi tujuan mahasiswi tampil beda di lingkungan FISIP adalah : (1) ingin menjadi pusat perhatian; (2) menarik perhatian lawan jenis; (3) lebih percaya diri; (4) tidak suka menggunakan barang yang sama. Berikut akan dijelaskan lebih rinci.

102 | Jurnal Ilmu Sosial dan Ilmu Politik Malikussaleh (JSPM) Volume 1 Nomor 1 Tahun 2020 


\section{Keinginan Menjadi Pusat Perhatian}

Jika berbicara tentang penampilan, gaya, dan keinginan tampil beda tentu tak lepas dari pembicaraan tentang fashion. Hal ini berarti berbicara tentang apa yang ingin ditunjukkan kepada orang lain. Seseorang membuat penampilannya berbeda dari orang lain karena ingin menunjukkan sesuatu pada orang lain.

Penampilan yang menarik dengan memakai produk-produk fashion akan membuat mereka menjadi orang yang sangat bersemangat dalam hidupnya, dan dapat dengan mudah mendapatkan apa yang mereka inginkan. Tampil berbeda dengan menggunakan barang yang unik dari produkproduk fashion serta gaya hidup yang mengikuti perkembangan zaman membuat mereka seolah menjadi selebriti yang diidam-idamkan oleh para penggemarnya. Berikut hasil wawancara dengan RA (21), salah satu mahasiswi Program Studi Sosiologi yang menyatakan bahwa:

“... gak ada tujuan sih, cuma senang beda aja. Ya mungkin jadi pusat perhatian, karena kita beda dan punya gaya sendiri dibanding orang dan gak ikut-ikutan sama gaya atau penampilan orang." (RA, Bukit Indah, 05/03/2018)

Dari hasil wawancara di atas dapat diketahui bahwa tujuan dari tampil beda dari orang lain adalah ingin menjadi pusat perhatian dan ingin punya gaya sendiri tanpa mengikuti gaya orang lain. Dengan tampil beda dapat menunjukkan bahwa seseorang dapat menciptakan gaya atau penampilan yang sebelumnya tidak ada pada orang lain. Tampil berbeda dan lebih cantik dari orang lain sudah menjadi keinginan setiap perempuan. Agar terus tampil berbeda dari yang lain seseorang akan mulai mempersonalisasi barang-barang tertentu yang diidentikkan dengan diri mereka. Menganggap sebuah barang tunggal dan hanya dimiliki oleh dirinya seorang sehingga jika memakainya tidak akan ada orang lainnya yang akan menggunakannya, merasa dirinya berbeda dan kemudian mendapat perhatian dari orang lain karena tampil berbeda di lingkungannya. Hal serupa disampaikan C (21), salah satu mahasiswi Program Studi Sosiologi yang menyatakan bahwa:

“... tujuan... biar tampil beda aja sih. Gak ada tujuan lain, ya maunya jadi pusat perhatian, dipuji dan kalo dibilang cantik, bagus kan kitanya juga senang” (C, Bukit Indah, 22/03/2018).

Pakaian memiliki pesan artifaktual yang ditampakkan melalui penampilan tubuh. Cara seseorang berbusana selalu dinilai oleh orang lain (Trisnawati, 2011). Maka kebergayaan menjadi penting karena orang yang tidak bergaya akan menerima beragam sanksi dari lingkungan pergaulannya (Hendariningrum \& Susilo, 2008). Tampil berbeda merupakan sebuah kebutuhan 
sekaligus sebagai ekspresi diri dan komunikasi dari pemakainya. Pakaian yang mengikuti mode mencerminkan kepribadian dan citra diri. Hal itulah yang dirasakan oleh S (21), salah satu mahasiswi Program Studi Sosiologi yang menyatakan bahwa:

“... orang-orang kan bakalan tanyain ke kita kak, eh beli dimana, bagus ya, kita kan jadi mencolok terus diperhatiin sama orang kita jadi pusat perhatian kak" (S, Bukit Indah, 05/03/2018).

Dari hasil wawancara di atas dapat dipahami bahwa tujuan seseorang tampil berbeda dengan yang lain karena ingin tampil mencolok di ruang sosialnya dan menjadi pusat perhatian. Perempuan akan sangat senang menjadi pusat perhatian orang lain, senang ditanyai dan dijadikan referensi bagi orang lain. Tetapi tetap berkeinginan bahwa penampilannya tunggal dan tak ingin sama atau mirip dengan orang lain bahkan dengan teman sendiri. Selanjutnya wawancara dengan AF (22), salah satu mahasiswi Program Studi Sosiologi diperoleh keterangan:

“... Sebenarnya gak ada niat yang signifikan, kek mana ya mungkin pas itu kita, kita sendiri yang berbeda dari orang lain, jadi senang gitu. Senang kan kalo orang-orang tanyain sama kita tentang yang gak ada sama orang lain. Gak ada niat tertentu" (AF, Bukit Indah, 22/03/2018).

Dari hasil wawancara di atas informan mengaku bahwa berpenampilan menarik atau berbeda di ruang sosialnya adalah untuk menunjukkan sesuatu, menunjukkan pada orang lain apa yang kita punya dan akan menjadi tontonan bagi orang lain. Mahasiswi lebih tertarik dalam mode daripada orang yang lebih dewasa. Namun masalahnya kebanyakan mahasiswi tidak memiliki penghasilan yang cukup menopang gaya hidupnya. Oleh karena itu mereka melakukan berbagai pola adaptasi agar dapat mengakomodasi selera mode berpakaian mereka.

Dari hasil wawancara di atas dapat diketahui bahwa yang menjadi tujuan seseorang melakukan pembedaan diri adalah mendapat kesenangan tersendiri, ingin menjadi pusat perhatian, ingin menunjukkan pada yang lain bahwa gaya atau penampilannya cantik. Manusia adalah makhluk hidup yang tak bisa hidup sendiri, maka dari itu selalu menginginkan perhatian orang lain, rela melakukan apapun agar mendapat pujian dan perhatian orang lain. Apa yang dilakukan seseorang atas usaha ingin diperhatikan oleh orang lain. Menjadi pusat perhatian memang sesutau yang menyenangkan bagi seorang perempuan. Para mahasiswi menggunakan pakaian bukan lagi pada kebutuhan biologis namun sudah beralih pada keinginan untuk memuaskan hasrat diri yang ingin dipuji dan menjadi pusat perhatian di lingkungannya atau memamerkan apa yang ia punya. Zaman sekarang seseorang selalu ingin menunjukkan sesuatu pada orang lain, ingin menjadi tontonan bagi orang lain yang dianggap cantik. Jika sudah tampil berbeda dari orang lain dan

104 | Jurnal Ilmu Sosial dan Ilmu Politik Malikussaleh (JSPM) Volume 1 Nomor 1 Tahun 2020 
mencolok di lingkungannya, maka perhatian akan tertuju pada diri si pemakai tampilan tersebut. Maka tampil berbeda haruslah kontinue agar perhatian itu terus ada dan melekat.

Tampil beda sepertinya telah menjadi kebiasaan, motivasi, atau sesuatu yang mendorong seseorang untuk terus berpenampilan tunggal di ruang sosialnya adalah karena ingin menjadi pencipta tren di lingkungannya, menjadi kenyamanan dan kesenangan tersendiri bagi penggunanya. Perempuan cenderung menghindari penampilan yang sama dengan orang lain karena ingin menjadi yang paling menarik, unik, dan diperhatikan oleh lingkungannya. Informan $\mathrm{S}$ mengungkapkan:

“... gak suka kali sama kawan sendiri, tapi suka ikut-ikut... maksudnya gini kak, kalo dia gak bilang, lihat kita ikut, benci saya. Tapi kalo misalnya dia bilang, kita beli ini yok, maksudnya bareng-barengan belinya yok, kalo ada yang sama keknya baju itu udah gak mau pakek lagi, rasanya baju itu keknya kasih ke orang aja, apalagi yang pake itu misalnya orang-orang jauh sana orang kampung sana itu keknya gak mau lagi pakek baju itu keknya." (S, Bukit Indah, 05/03/2018).

Dari wawancara di atas dapat disimpulkan bahwa perempuan tidak suka memakai barang yang sama dengan orang lain bahkan dengan teman sendiri. Seseorang akan merasa risih jika memiliki barang yang sama dengan yang lain tanpa ada kesepakatan sebelumnya. Dan jika ada yang memakai barang yang sama dengannya rasanya ia tidak ingin lagi memakai pakaian itu, terlebih lagi jika yang memakai barang tersebut merupakan orang yang dianggap kampungan dan memiliki selera rendah, sehingga lebih baik memberikan barang tersebut kepada orang lain. Hasil wawancara dengan RA (21) diperoleh keterangan memperkuat pandangan tersebut:

“enggak suka, gak tau aja... kayak pasaran, sama gitu. Misalkan kita pake tas yang sama noleh ke kanan dia sama juga noleh kiri dia juga, kayak ngerasa enggak nyaman aja. ...gak suka, gak pede, apalagi kalo yang kebetulan, yang make baju itu keliatan kampungan... padahal bisa dibilang mode sekarang tapi pas ngeliat dia yang pake... orang yang kampungan... jadi keliatan gak suka lagi baju itu...." (RA, Bukit Indah, 05/03/2018).

Dari wawancara diatas dapat diketahui bahwa perempuan tidak suka memiliki atau memakai barang yang sama dengan orang lain karena merasa "pasaran”. Merasa tidak nyaman bila memakai barang yang sama dengan orang lain. Seorang perempuan jika memakai sesuatu barang akan lebih sensitif untuk melihat keadaan sekitar, takut dan tidak nyaman jika ada yang memakai barang yang sama, sehingga membuat para perempuan lebih berhati-hati dalam menggunakan suatu barang, karena mereka ingin tampil berbeda dari yang lain, tidak ingin gayanya atau barang miliknya sama dengan yang lain, karena takut dianggap "pasaran”. Terlebih jika mereka kebetulan memakai barang yang sama dengan orang yang tidak mereka sukai, mereka menjadi lebih sensitif lagi. Hal ini sebagaimana pandangan Bourdieu yang memaparkan bahwa konsumsi dilakukan 
untuk tujuan pembedaan sosial. Ia berpendapat bahwa gaya hidup adalah suatu area penting bagi pertarungan pelbagai kelompok dan kelas sosial. Konsumsi budaya itu cenderung mengisi suatu fungsi sosial berupa melegitimasi perbedaan-perbedaan sosial (Storey, 2017).

\section{Menarik Perhatian Lawan Jenis}

Kemenarikan fisik dan penampilan diri di lingkungan dapat menjadi faktor penentu untuk seseorang dicintai oleh orang lain, dimana seorang laki laki akan lebih tertarik pada perempuan yang dianggap berpenampilan menarik, berbeda, dan unik. Tampil beda sudah tentu harus dijalankan oleh setiap perempuan, jika ingin terus diperhatikan dan mendapatkan pujian serta rasa ketertarikan pada lawan jenis. Berpenampilan menarik dan berbeda adalah termotivasi dari keinginan mendapat perhatian dari lawan jenis. Informan I (20) menyatakan:

“Apalagi tujuannya sih? ... pokoknya kalo kita udah nyaman, udah rapi... tujuannya pasti menarik orang lain... ya kayak cowok. Sebenarnya setiap perempuan pasti ingin jadi pusat perhatian" (I, Bukit Indah, 22/03/2018).

Hal serupa disampaikan oleh R (19), salah satu mahasiswi Program Studi Sosiologi yang menyatakan:

“... Sebenarnya gak ada tujuan apa-apa kak, dilihat cowok mungkin... rasa suka sama seseorang pasti ada, jadi kita termotivasi untuk harus tampil rapi... harus ini... harus itu...." (R, Bukit Indah, 22/03/2018).

Penampilan fisik mempengaruhi berbagai jenis reaksi termasuk rasa suka dan respon orang. Hal ini sangat terkait dengan apa yang mereka kenakan (Azhar, 2014). Pada umumnya kaum perempuan mempunyai kepedulian yang lebih besar terhadap penampilan fisik dibandingkan kaum laki-laki. Penampilan sangatlah penting sebagai basis kepercayaan diri dan rasa bangga. Tujuan seorang perempuan tampil beda di ruang sosialnya adalah menarik perhatian lawan jenis. Apalagi bila penampilan tersebut dapat memikat lawan jenis dan orang yang disukai yang dapat memotivasi untuk terus tampil rapi dan cantik. Ketika seseorang melakukan sesuatu karena terdorong rasa perlu akan sesuatu maka seseorang tersebut akan melakukan apapun untuk mendapatkannya.

\section{Lebih Percaya Diri}

Penampilan meningkatkan rasa percaya diri. Percaya diri sangatlah diperlukan agar kita mampu menilai diri kita secara positif. Berikut wawancara dengan RA (21), salah seorang informan penelitian:

“... ngerasa pede, kalo orang mau niru style aku... tapi aku gak suka kalau untuk niru-niru style orang itu... kalo aku beli baju sih lebih cenderung memilih yang nyaman walaupun 
kadang-kadang baju tersebut modelnya udah lama ataupun udah gak fashion lagi. Tapi kalo kira-kira itu masih nyaman untuk dipake ya istilahnya nyaman untuk dikenakan gak peduli itu baju tempo dulu kek dibilangnya. Biar tampil beda.” (RA, Bukit Indah, 05/03/2018)

Mode memang selalu berubah-ubah dan terus diperbaharui dari waktu ke waktu dengan bertitik tolak pada mode sebelumnya dan akan berulang pada kurun waktu tertentu. Tetapi gaya klasik akan tetap ada dan akan tetap disukai oleh sebagian orang yang memang ingin tampil berbeda dari orang lain dan ingin eksis di ruang sosialnya.

Sudah lumrah bagi setiap perempuan yang ingin hanya dirinya lah yang paling bagus, paling cantik, dan paling lainnya. Merasa senang akan hal itu pun menjadi kebiasaan bagi para perempuan, sehingga diwujudkan dengan memakai barang yang berbeda dari orang lain. Tak ayal jika para perempuan selalu berlomba-lomba untuk terus tampil berbeda. Informan AF mengungkapkan:

"senang, karena itu limited edition dong. kadang-kadang kita kalau bedanya positif pede ajakan, selama kita jalan yang bener ya pede aja. Kalo yang pas-pas kita selera kita lagi gimana-gimana mencolok atau gimana-gimana warnanya atau gimana jadikan orang liatnya berbeda.” (AF, Bukit Indah, 22/03/2018).

Bagi para pencari citra diri, untuk terus dapat membuat dirinya memperoleh pengakuan dan dianggap menarik, maka membedakan diri adalah hal yang harus terus dilakukan. Informan C (21) menambahkan:

"lebih percaya diri karenakan beda dari orang lain dan gak ada tujuan lain sih, cuma kan lebih menarik aja kalo dilihat beda dari orang lain" (C, Bukit Indah, 22/03/2018).

Percaya diri memang menjadi salah satu bagian penting dalam diri seorang perempuan. Percaya diri sangatlah diperlukan agar kita mampu menilai diri kita secara positif. Menggunakan barang yang berbeda dan tampil beda dari orang lain membuat kepercayaan diri perempuan meningkat dan merasa tampil berbeda akan lebih menarik dilihat oleh orang lain di sekitarnya. Penampilan sangatlah berpengaruh pada kepercayaan diri seorang perempuan. Hal itu akan memberi perasaan aman dalam menghadapi lingkungannya.

\section{Tidak Suka Menggunakan Barang yang Sama}

Dengan banyaknya industri dan perusahaan yang memproduksi barang (pakaian) dalam jumlah yang besar, barang-barang yang sama diproduksi oleh produsen lalu disebarkan. Pada dasarnya perempuan tidak ingin tampil atau terlihat sama dengan orang lain, jika terlihat sama ia akan merasa risih, terganggu, dan sebagainya. Hasil wawancara dengan informan I (20) diperoleh keterangan: 
“... gak senang karena perempuan itu gak boleh disamakan... jangan ada sama lah sama orang. Kalo ada sama, kita jadi susah, gak enak dipandang.” (I, Bukit Indah, 22/03/2018)

Sedikit perbedaan dengan keterangan di atas, informan R (19) mengatakan:

“... kalo menurut saya sama atau bedanya itu gak masalah kak, yang penting itu kan hak orang lain untuk menggunakan fashion itu sendiri. Gak papa sama itu juga hak orang lain." (R, Bukit Indah, 22/03/2018)

Hal serupa disampaikan oleh AF (22), salah satu mahasiswi Program Studi Sosiologi:

"kalo modelnya menurutku, aku suka walaupun sama aku pede aja, gak masalah kalo aku suka sama baju itu, karena simpel. Kalo gak simpel ya gak suka... juga itu rasanya lucu, abis itu yang memproduksi baju itukan bukan cuma satu, yang lain kan berhak memakainya. Kecuali diejek-ejek di-bully baru rasanya palak, marah. Gak suka diejek, itukan kita terserah kita mau pake baju apa, tapi kan kalo diejek jadi bad mood. Gak suka diejek pokoknya.” (AF, Bukit Indah, 22/03/2018)

Bourdieu menyatakan habitus terbentuk akibat logika praktik, yang berarti individu ditentukan oleh seperangkat kondisi materi tertentu. Walaupun habitus memberi kerangka untuk bertindak, namun ia tidak statis dan dapat dibentuk oleh strategi-strategi yang diadopsi oleh berbagai kelompok sosial (Lury, 1998). Dari seluruh hasil wawancara di atas dapat dipahami bahwa kebanyakan dari perempuan ingin tampil berbeda dan menarik, tapi tidak ingin tampil sama

dengan yang lain. Namun ada sebagian perempuan yang tidak terlalu peduli memakai barang yang sama dengan yang lain, meskipun perempuan sangat sensitif jika dikritik pada penampilannya.

Mahasiswi yang menjadi informan penelitian mempersonalisasi barang-barang tertentu dan menganggap dirinya tunggal sehingga mahasiswi lain pun berpikir seperti itu, dan hal itu menyebar. Orang lain memiliki kerangka berpikir seperti itu karena terpengaruh oleh lingkungannya. Saat satu orang berpikir seperti itu dan yang lain mengikuti maka dari itu terbentuklah habitus yang mana orang mulai berpikir bahwa inilah yang harus dilakukan, tampil berbeda atau penampilan tunggal di lingkungan itu sebuah keharusan, alhasil menjadi struktur yang menstruktur yang lainnya.

\section{PERILAKU KONSUMTIF MAHASISWI FISIP UNIMAL}

Perilaku konsumtif diiringi irasionalitas dan kompulsif, dengan tujuan kesenangan diri. Hal ini sebenarnya sebagai bentuk demonstrasi kekayaan dan status (Veblen dalam Suminar \& Melyuntari, 2015; Bakti, et al., 2020). Perilaku konsumtif adalah mengonsumsi barang atau jasa di luar kebutuhan rasional (Lubis dalam Fitriyani, et al., 2013). 


\section{Membeli Barang}

Berbelanja memang sebuah aktivitas yang menyenangkan bagi kebanyakan perempuan. Berbelanja berkembang menjadi sebuah cerminan gaya hidup tidak terlepas dari adanya keterlibatan fashion sebagai pemuas keinginan. Keterlibatan fashion itu sendiri membuat para konsumen memiliki rasa ketergantungan terhadap dunia fashion, mendorong perilaku konsumtif dengan pembelian tanpa perencanaan yang matang.

\section{a. Berdasarkan Trend}

Trend terkait apa yang sedang digandrungi atau sedang "menjamur" di tengah masyarakat. Informan S (21) dan C (21) menyatakan:

“... kalo misalkan mau beli barang lihat trend dulu, kalo kebanyakan di instagram itu. Lihat trend-nya rame atau akan rame... kalo kita lihat di jalan pun, orang itu semua pake baju itu. Itu saya gak akan beli lagi, kecuali memang udah suka kali.” (S, Bukit Indah, 05/03/2018)

"gini sih, lihat keadaan trend-nya dulu... pengin punya barang itu yang unik ya, yang orang lain gak pake tapi kita punya..." (C, Bukit Indah, 22/03/2018)

Dari hasil wawancara di atas dapat disimpulkan bahwa saat membeli sesuatu keunikan pada barang sangat diperhatikan, karena pada dasarnya perempuan menyukai sesuatu yang unik-unik dan berbeda dari orang lain sehingga hanya ada pada dirinya. Belanja atau membeli barang lebih merupakan “interaksi simbolis dimana individu membeli dan mengonsumsi kesan”. Yang dibeli adalah kesan dan pengalaman yang selama ini dipertontonkan di ruang sosial (Featherstone dalam Rafa'al, 2017). Perkiraan dalam membeli suatu barang adalah melihat keadaan sekitar apakah barang tersebut akan meledak atau banyak digunakan oleh orang lain atau tidak. Jika sudah banyak yang menggunakan barang tersebut berarti barang tersebut tidak dibeli, karena para mahasiswi takut akan menggunakan barang yang sama dengan yang lain.

\section{b. Berdasarkan Daya Beli}

Banyak orang yang mengatakan barang bagus itu didasarkan atas mutu dan kualitasnya. Mutu barang berhubungan dengan harga dan produsennya. Wawancara dengan RA (21) dan AF (22) diperoleh informasi:

“... yang aku lihat kualitasnya, kedua nyaman gak dipake... terus pertimbangan paling besar harga, ngeliat dulu di sekitar... pantau dulu fashion apa sekarang... misalnya tas... gimana model sekarang... kalo kira-kira tas tersebut terlalu pasaran... terlalu rame yang pake di kampus itu aku pasti gak beli." (RA, Bukit Indah, 05/03/2018) 
"harganya murah, gak cepet habis modelnya, kayak kita pake baju polos kan, panjang polos gak akan luntur-luntur modelnya. Yang bisa dipake bertahun-tahun, yang misalkan kita pake tahun ketujuh pun atau tahun keberapapun gak buat kita gak gimana-gimana dan tetap in gitu." (AF, Bukit Indah, 22/03/2018)

Pada umumnya konsumen mahasiswi mempunyai keinginan membeli barang yang tinggi, mempunyai ciri khas dalam berpakaian dan berdandan. Tetapi mereka juga harus menyesuaikan diri dengan harga produk yang dikonsumsi.

\section{Pola Membeli Barang}

Trend mempengaruhi fashion anak muda. Ada begitu banyak hal yang ditawarkan pada masa sekarang. Barang-barang diproduksi dalam skala besar membuat barang tersebut tidak tunggal dan tentunya akan ramai di pasaran. Dengan berkembangnya internet yang memudahkan para penggunanya, olshop (online shop) pun hadir, sehingga membantu para pemburu fashion memuaskan hasrat mereka. Memantau online shop merupakan salah satu cara saat ingin membeli barang, karena umumnya fashion ter-update akan sangat mudah menyebar di online shop, sehingga kita akan mengetahui benda-benda mana yang sudah banyak dipakai oleh orang lain. Dengan cara seperti itulah seseorang menentukan apa yang akan ia beli agar tidak membeli barang yang sama dengan orang lain.

Pola membeli barang dapat digambarkan dimana seorang membeli barang bukan berdasarkan pada kebutuhan melainkan pada rasa suka dan rasa ingin berbeda dengan orang lain. Alhasil konsumsi jenis ini telah membentuk kehidupan sosial manusia, membudaya, mendominasi, meresapi, serta memenuhi hasrat tak terbatas dengan kemampuan yang terbatas (Rafa'al, 2017). Konsumsi kemudian mengarah kepada keinginan menunjukkan sesuatu kepada orang lain bahwa hanya dia seorang yang memiliki barang atau tampilan tunggal. Para mahasiswi berusaha menunjukkan bahwa dengan kemampuan terbatas tapi bisa berkreasi tak terbatas.

\section{Bagan 1. Skema Pola Membeli Barang}

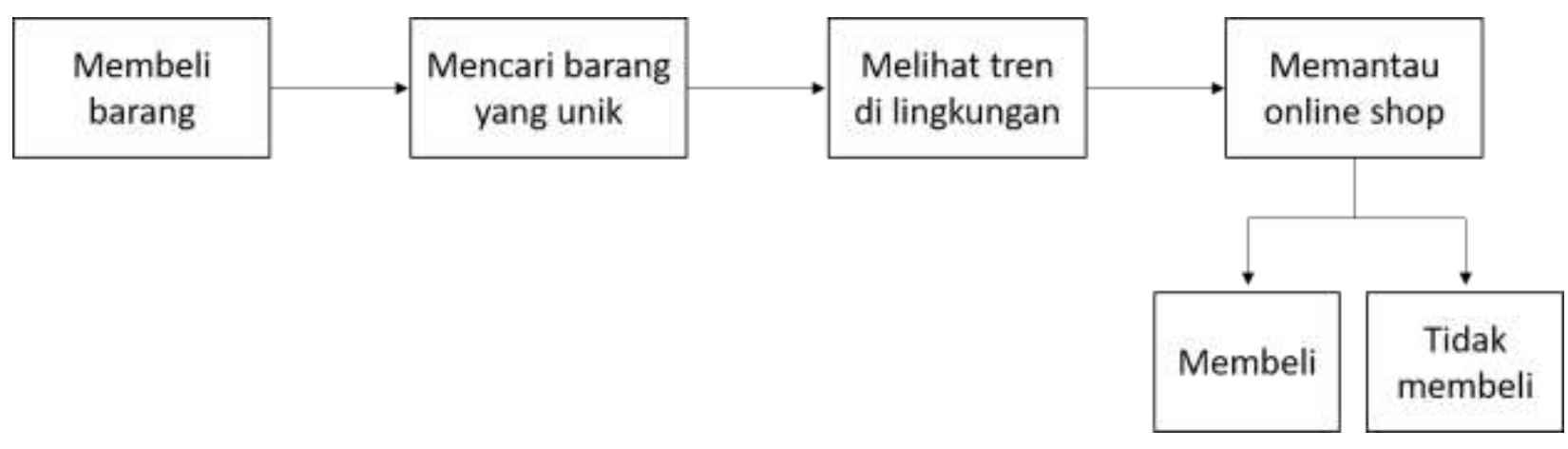




\section{KESIMPULAN}

Busana seseorang mengindikasikan dari kelompok mana ia berasal. Diri, status, dan gender dinyatakan secara kuat melalui pakaian dan dandanan. Berdasarkan hasil penelitian dan pembahasan dapat ditarik beberapa kesimpulan. Pertama, para mahasiswi di Program Studi Sosiologi Fakultas Ilmu Sosial dan Ilmu Politik Universitas Malikussaleh ingin tampil beda disebabkan oleh beberapa hal, yaitu: (1) Keinginan menjadi pusat perhatian. Setiap perempuan sangat senang diperhatikan oleh orang lain, oleh sebab itu tujuan melakukan tampil beda dari orang lain adalah ingin menjadi pusat perhatian; (2) Keinginan menarik perhatian lawan jenis; (3) Keinginan menjadi trendsetter, di mana perempuan ingin menjadi referensi bagi orang lain. Jadi bukan hanya sekedar ikut-ikutan orang lain tapi dialah yang diikuti oleh orang-orang yang di sekitarnya; (4) Merasa lebih percaya diri. Ketika mahasiswi menggunakan barang yang berbeda dari orang lain maka ia merasa kepercayaan dirinya muncul dan lebih siap menghadapi lingkungannya.

Kedua, konsumsi bukan lagi terkait dengan nilai-guna, melainkan konstruksi dan rekonstruksi identitas diri. Mahasiswi di Program Studi Sosiologi dalam hal mengkonsumsi barang bukanlah pada kebutuhan pokok saja, tetapi dalam hal berbelanja atau membeli barang didasarkan pada lingkungannya, yaitu agar tidak sama dengan orang lain. Mereka terfokus untuk terus memperhatikan lingkungannya, bukan membeli barang atas dasar fungsi.

Peneliti memahami bahwa percaya diri merupakan kunci utama agar kita selalu memiliki pandangan positif tentang siapa diri kita dan apa potensi yang ada dalam diri kita sehingga mampu membuat orang memperhatikan bahkan mencintai kita. Namun yang dinilai oleh orang lain bukan hanya sekedar penampilan fisik. Cara berpikir dan sikap jualah yang kemudian membuat orangorang akan menganggap kita ada.

\section{DAFTAR PUSTAKA}

Astuti, E. D. (2013). Perilaku Konsumtif dalam Membeli Barang pada Ibu Rumah Tangga di Kota Samarinda. Psikoborneo, 1(2), 79-83.

Azhar (2013). Peranan Daya Tarik Fisik terhadap Perasaan Cinta pada Lelaki yang Memiliki Wanita dengan Tunanetra. Psikoborneo, 1(4), 237-240.

Bakti, I. S., Nirzalin, \& Alwi (2019). Konsumerisme Menurut Perspektif Jean Baudrillard. Jurnal Sosiologi USK, 13(2), 146-165. 
Bakti, I. S., Anismar, \& Amin, K. (2020). Pamer Kemewahan: Kajian Teori Konsumsi Thorstein Veblen. Jurnal Sosiologi USK, 14(1), 81-98.

Bourdieu, P. (2010). Arena Produksi Kultural: Sebuah Kajian Sosiologi Budaya. Kreasi Wacana.

Chaney, D. (1996). Lifestyle: Sebuah Pengantar Komprehensif. Jalasutra.

Fitriyani, N., Widodo, P. B., \& Fauziah, N. (2013). Hubungan antara Konformitas dengan Perilaku Konsumtif pada Mahasiswa di Genuk Indah Semarang. Jurnal Psikologi, 12(1), 1-14.

Hendariningrum, R., \& Susilo, M. E. (2014). Fashion dan Gaya Hidup: Identitas dan Komunikasi. Jurnal Ilmu Komunikasi, 6(1).

Hotpascaman, S. (2010). Hubungan antara Perilaku Konsumtif dengan Konformitas pada Remaja. Skripsi. Program Sarjana Psikologi Universitas Sumatera Utara.

Jenkins, R. (2004). Membaca Pikiran Bourdieu. Kreasi Wacana.

Lury, C. (1998). Budaya Konsumen. Yayasan Obor Indonesia.

Moleong, L. J. (2014). Metodologi Penelitian Kualitatif. Remaja Rosda Karya.

Pertiwi, M. M. C. A., \& Bharata, B. S. (2012). Budaya Populer dan Pesan Persuasif Majalah Perempuan.

Piliang, Y. A. (2011). Dunia yang Dilipat: Tamasya Melampaui Batas-batas Kebudayaan. Matahari.

Pratiwi, G. I. (2015). Perilaku Konsumtif dan Bentuk Gaya Hidup (Studi Fenomenologi pada Anggota Komunitas Motor Bike of Kawasaki Riders Club (BKRC) Chapter Malang). Jurnal Mahasiswa Sosiologi, 1(5).

Rafa'al, M. (2017). Identitas Gaya Hidup dan Budaya Konsumen dalam Mengkonsumsi Brand The Executive. Jurnal Komunikasi Profesional, 1(1).

Ramadhani, T. N., \& Putrianti, F. G. (2014). Hubungan antara Kepercayaan Diri dengan Citra Diri pada Remaja Akhir. SPIRITS, 4(2), 22-32.

Ritzer, G. (2010). Teori Sosial Postmodern. Kreasi Wacana.

Ritzer, G. \& Goodman, D. J. (2003). Teori Sosiologi Modern. Kencana.

Sari, D. N. (2014). Perbedaan Gaya Hidup Mahasiswa Ditinjau dari Status Ekonomi dan Jenis Kelamin pada Mahasiswa Jurusan Manajemen Ekstensi Fakultas Ekonomi Universitas Mulawarman. Psikoborneo, 2(2).

Soedjatmiko, H. (2008). Saya Berbelanja Maka Saya Ada: Ketika Konsumsi dan Desain Menjadi Gaya Hidup Konsumeris. Jalasutra.

Storey, J. (2017). Theories of Consumption. Routledge.

Sugiyono (2013). Memahami Penelitian Kualitatif. Alfabeta.

112 | Jurnal Ilmu Sosial dan Ilmu Politik Malikussaleh (JSPM) Volume 1 Nomor 1 Tahun 2020 
Suminar, E., \& Meiyuntari, T. (2015). Konsep Diri, Konformitas dan Perilaku Konsumtif pada Remaja. Persona: Jurnal Psikologi Indonesia, 4(2).

Trisnawati, T. Y. (2016). Fashion sebagai Bentuk Ekspresi Diri dalam Komunikasi. Jurnal The Messenger, 3(2), 36-47.

Ulfa, N. S. (2017). Konsumsi sebagai Penanda Kesejahteraan dan Stratifikasi: http://download.portalgaruda.org/article.php?article=23010\&val=1295, diakses 20/10/2017

Wahyudin, U., \& Purwaningwulan, M. M. (2017). Konsumerisme pada Iklan Majalah Perempuan. JIPSI-Jurnal Ilmu Politik dan Komunikasi UNIKOM, 7(1). 